\title{
ACOUSTIC TUMOURS
}

\author{
BY \\ H. OLIVECRONA
}

From the Neurosurgical Clinic, Serafimerlasarettet, Stockholm, Sweden *

(ReCEIVED 27th February, 1940)

IN the literature the paper of List (1932) covering Cushing's material is the single example of a comprehensive statistical survey of the immediate and late results concerning operations for acoustic tumours. Even List's paper, valuable though it is, does not bring sufficient information to enable the reader to form his own opinion concerning the late results, especially earning capacity and morbidity among the survivors. This scarcity of reports indicates, to my mind, that the results are poor, and I am afraid we must confess that the results of surgery in acoustic tumours are not comparable to those obtained in other types of benign tumours. This, of course, has always been so, only the problems have shifted in so far as we now are not so much concerned with the immediate mortality, which has been reduced to reasonable proportions, but with the late results.

\section{Intracapsular Enucleation}

In 1933 I reported my experiences with the intracapsular enucleation up to 1st June, 1930. The results are shown in Table 1. In the bottom row of this table are the figures as they appear when this table is brought up to date. The late mortality due to recurrences has now risen to 56 per cent. of those surviving operation, or 41 per cent. of the total number of cases. Among the cases still living there are three cystic tumours which are all completely well. Three or four of the remaining cases are also well ; the rest are invalids. It is obvious that in the case of the cystic tumours and of those with solid tumours which are well after 10 years or more, the tumour has not continued to grow. We can therefore count upon about 10 per cent. of the acoustic tumours being cystic and another 10-20 per cent. to be stationary, a statement that is also born out by some of List's figures. Unfortunately there is no way of knowing at operation whether a solid tumour is growing or not.

TABle 1.-InTRaCapsular EnUCleations 1923-1930

\begin{tabular}{|c|c|c|c|c|}
\hline $\begin{array}{l}\text { NO. OF } \\
\text { CASES }\end{array}$ & MORTALITY & $\begin{array}{l}\text { DIED LATER OF } \\
\text { RECURRENCE }\end{array}$ & $\begin{array}{l}\text { AVERAGE SURVIVAL } \\
\text { PERIOD AMONG } \\
\text { LATE DEATHS }\end{array}$ & $\begin{array}{l}\text { AVERAGE SURVIVAL } \\
\text { PERIOD OF THOSE } \\
\text { STILL LIVING }\end{array}$ \\
\hline $\begin{array}{l}34 \\
34\end{array}$ & $\begin{array}{l}9 \text {, or } 27 \cdot 7 \% \\
9 \text {, or } 27 \cdot 7 \%\end{array}$ & $\begin{array}{l}12, \text { or } 48 \% \\
14 \text {, or } 56 \%\end{array}$ & $\begin{array}{l}3 \text { years } \\
3 \text { 3/4 years }\end{array}$ & $\begin{array}{r}5 \text { years } \\
10 \text { years } \\
\end{array}$ \\
\hline
\end{tabular}

* Read at the Third Neurological Congress, Copenhagen, 1939. 
Except in the case of stationary tumours the results obtained with the intracapsular operation were extremely poor. All the other cases died from recurrence, usually within 4 years. Their period of relief was also comparatively short, signs of recurrence usually appearing within two or three years, and hardly any of these cases was really well and fully capable of work for any considerable time.

From List's paper we know that Cushing gradually brought down the immediate mortality in the intracapsular operation to a very low figure. However, the late results do not appear to be much different from those obtained in the above series. Thus, of the survivors of the operation who could be traced, 27.2 per cent. died from recurrence after an average survival period of nearly 5 years. That this figure is no greater probably depends upon the relatively very large number of patients who were operated on during the last three or four years and therefore would not begin to figure in the recurrence mortality statistics until some years later. It would be of great interest if the statistics of List were brought up to date.

With regard to morbidity among the survivors 31 per cent. of the traceable survivors were complete invalids, another 31 per cent. practically complete invalids, but they were able to help themselves and had no subjective complaints. Thirty-eight per cent. were partially or completely able to work.

It does not seem unreasonable to expect that if List's statistics were carried up to date they would indicate that perhaps 20-30 per cent. of the total number of cases harbour inactive lesions, which do very well provided the intracapsular operation has been sufficiently complete to release the cerebrospinal fluid pathways, but that the remaining cases are dead from recurrence, being more or less incapacitated during their survival period.

\section{Radical Operation}

Before turning our attention to my material from 1930 onwards it is necessary to say a few words concerning the terminology to be used. By radical or complete removal is understood that all macroscopically visible tumour tissue has been removed. A subtotal removal is one where complete removal has been attempted but found to be impossible, usually because of technical difficulties which made the danger of causing irreparable damage to the brain stem too great. An intracapsular enucleation, finally, is an operation which is deliberately incomplete. As executed during the last 10-12 years it coincides fairly well with what List has called radical intracapsular enucleation in his statistics.*

A general survey of the results with regard to immediate and remote mortality is shown in Table 2. The mortality is lowest in the group of radical operations. This seems surprising ; the reason is that into this group fall the majority of favourable cases ; moreover the control of haemorrhage is more reliable when no trace of tumour is left behind. The subtotal removals are a less favourable group ; they consist of cases where the technical difficulties

* My assistant, Dr. Aage Nielsen, has collected and followed up the entire material. His study will be published in the near future. 
were greater than in the preceding group, though the most dangerous step in the radical removal of an acoustic tumour, the dissecting of the internal stalk of the tumour from the pons, was omitted. The fact that it has been attempted, however, in the majority of these cases probably accounts for the comparatively high mortality.

TABle 2.-Acoustic Tumours, 1930-1939

\begin{tabular}{|c|c|c|c|c|c|c|}
\hline & & $\begin{array}{l}\text { NO. OF } \\
\text { CASES }\end{array}$ & $\begin{array}{c}\text { NO. OF } \\
\text { OPERATIONS }\end{array}$ & $\begin{array}{l}\text { OPERATIVE } \\
\text { MORTALITY }\end{array}$ & $\begin{array}{c}\text { CASE } \\
\text { MORTAL. }\end{array}$ & DIED LATER \\
\hline $\begin{array}{l}\text { Complete extirpations } \\
\text { Subtotal extirpations } \\
\text { Intracaps. enucleations }\end{array}$ & $\begin{array}{l}\cdots \\
\cdots \\
\cdots\end{array}$ & $\begin{array}{l}75 \\
27 \\
28\end{array}$ & $\begin{array}{l}75 \\
28 \\
29\end{array}$ & $\begin{array}{r}14 \text {, or } 18.7 \% \\
6 \text {, or } 21 \cdot 4 \% \\
8 \text {, or } 27.6 \%\end{array}$ & $\begin{array}{l}18 \cdot 7 \% \\
22 \cdot 2 \% \\
28 \cdot 6 \%\end{array}$ & $\begin{array}{l}4 \text {, or } 6.6 \% \\
1 \text {, or } 5 \% \\
4 \text {, or } 20 \%\end{array}$ \\
\hline Total & $\ldots$ & 130 & 132 & 28 , or $20.7 \%$ & $21 \cdot 5 \%$ & 9 , or $8.8 \%$ \\
\hline
\end{tabular}

The intracapsular group is even less favourable in view of the operative results. The indications have been somewhat variable during the period covered by this statistical review-old age, poor general condition, a very advanced tumour stage being some of the principal reasons for not attempting a radical operation. In a number of cases the urgent necessity to save the facial nerve has been the deciding factor ; these cases might of course otherwise have been quite favourable for complete removal. The relatively high mortality also depends to a considerable extent upon the fact that a number belong to the early cases in the series.

The remote mortality in groups II and III was, in every case, due to recurrence of the tumour. In group I three cases died from old age, carcinoma of the stomach and septic infection, respectively, several years after the operation. In the fourth case a tumour " rest" the size of a pea was found attached to the pons at autopsy. Whether this tumour was the cause of death is uncertain.

Increasing experience has made it possible gradually to lower the mortality following radical removal of the tumour as is seen in Table 3.

TABLE 3

\begin{tabular}{|c|c|c|c|c|c|c|}
\hline YEAR & $\begin{array}{l}\text { No. } \\
\text { OF } \\
\text { CASES }\end{array}$ & $\begin{array}{c}\text { CASE } \\
\text { MORTALITY, } \\
\text { PER CENT. }\end{array}$ & DIED LATER & $\begin{array}{c}\text { FULL } \\
\text { EARNING } \\
\text { CAPACITY, } \\
\text { PER CENT. }\end{array}$ & $\begin{array}{l}\text { EARNING } \\
\text { CAPACITY } \\
\text { DIMINISHED, } \\
\text { PER CENT. }\end{array}$ & $\begin{array}{l}\text { UNABLE TO } \\
\text { WORK, } \\
\text { PER CENT. }\end{array}$ \\
\hline $\begin{array}{l}1931-33 \\
1933-35 \\
1935-37\end{array}$ & $\begin{array}{l}19 \\
19 \\
19\end{array}$ & $\begin{array}{l}26 \cdot 3 \\
21 \cdot 1 \\
21 \cdot 1\end{array}$ & $\begin{array}{c}1 \text { (old age) } \\
1 \text { (recurrence ?) } \\
2 \text { (sepsis, } \\
\text { carcinoma } \\
\text { stomach) } \\
0\end{array}$ & $\begin{array}{r}7 \cdot 7 \\
14 \cdot 3 \\
21 \cdot 4\end{array}$ & $\begin{array}{l}69 \cdot 2 \\
50 \\
50\end{array}$ & $\begin{array}{l}23 \cdot 1 \\
35 \cdot 7 \\
28 \cdot 6\end{array}$ \\
\hline
\end{tabular}

Turning our attention now to the post-operative morbidity as measured in terms of capacity for work, we find that comparatively few of the survivors ever attain full earning capacity. The intracapsular groups make a comparatively good showing because some of the bad cases have already died from 
recurrence. In the course of time only those cases having stationary tumours remain, and these will for the most part, when they have not become blind before operation, fall into the group of full earning capacity.

Among the radical and subtotal groups the majority have some defect which limits their capacity for work. These defects are of various kind and are sometimes difficult to define exactly, the most common being poor vision, cerebellar disturbances, general weakness. That cerebellar disturbances are less important than one might imagine is shown by the fact that the majority of survivors have normal gait and station (Table 4). It should also be taken into account that following a complete removal the time for convalescence and then for re-education is a long one, often a year or even two, and a number of the radicals who still use a stick are recent cases where the process of re-education has not yet been completed. Also this group is burdened by a number of early cases when the technique was still comparatively crude and where for this reason severe cerebellar disturbances and in two cases a more or less complete Wallenberg syndrome followed.

TABLE 4

\begin{tabular}{|c|c|c|c|c|c|c|c|c|c|c|c|}
\hline & 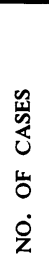 & 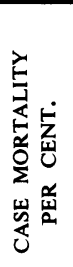 & 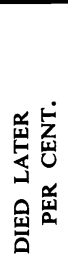 & 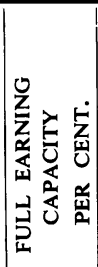 & 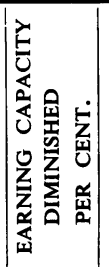 & 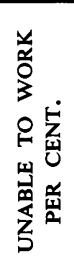 & 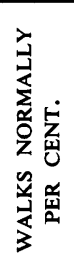 & 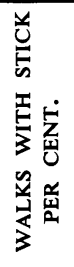 & 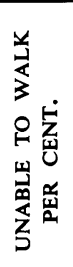 & 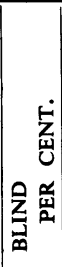 & 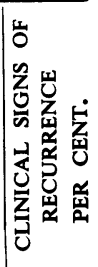 \\
\hline $\begin{array}{l}\text { Complete } \\
\text { extirpations... } \\
\text { Subtotal } \\
\text { extirpations .. } \\
\text { Intracaps. } \\
\text { enucleations }\end{array}$ & $\begin{array}{l}75 \\
27 \\
28\end{array}$ & $\begin{array}{l}18 \cdot 7 \\
22 \cdot 2 \\
28 \cdot 6\end{array}$ & $\begin{array}{c}6 \cdot 6 \\
5 \\
20\end{array}$ & $\begin{array}{l}14 \cdot 3 \\
15 \\
37 \cdot 5\end{array}$ & $\begin{array}{l}66 \cdot 1 \\
70 \\
37 \cdot 5\end{array}$ & $\begin{array}{l}19 \cdot 6 \\
15 \\
25\end{array}$ & $\begin{array}{l}54 \cdot 4 \\
65 \\
50\end{array}$ & $\begin{array}{l}42 \cdot 1 \\
30 \\
37 \cdot 5\end{array}$ & $\begin{array}{c}3 \cdot 5 \\
5 \\
12 \cdot 5\end{array}$ & $\begin{array}{r}5 \\
5 \\
10\end{array}$ & $\begin{array}{r}0 \\
10 \\
15\end{array}$ \\
\hline
\end{tabular}

That the rate of morbidity has been considerably improved upon is shown in Table 3 . In the last group of cases only 12.4 per cent. were completely unable to work, and these mainly on account of poor vision which had been present before operation. It is also certain that a large number of cases belonging to this last group who, at present, have a diminished capacity for work will in the course of time, when their re-education is completed, regain their full capacity for work.

I think it is fair to conclude that the intracapsular enucleation gives excellent results in those cases where the tumour is stationary or grows at an exceedingly slow rate. Unfortunately we cannot, except in the case of the cystic tumours, determine beforehand or at the time of operation the future behaviour of the growth. In the majority of cases, probably around 70 per cent., we have to face the presence of an actively growing tumour, and in these cases the only way to restore any considerable number of patients to health and social usefulness is to remove the tumour completely. 


\section{Post-operative Facial Palsy}

At this stage it is necessary to consider the facial nerve. Of all defects following radical removal of an acoustic tumour this is the most common and the most obvious. The facial disfigurement, which can at best be very incompletely improved by the various plastic and anastomosing operations, is always a very unpleasant sequel to an otherwise successful operation and may have very grave consequences for the individual, particularly in the case of young girls.

Isolated reports of saving of the facial nerve in operations entailing complete removal of acoustic tumours have appeared in the literature, but $I$ have been unable to find any reports on continued efforts in this direction or any statistics bearing on this problem. In my material the facial nerve has been saved occasionally more or less by chance in the earlier years of the radical operation. However, it was not until the dangers and difficulties of the radical operation had been to some extent overcome that systematic efforts to save the facial nerve were made, even when the tumour was completely removed. Since January 1937 an attempt in this direction has been made in every case. The number of complete extirpations done since January 1937-June 1939 was 23. The facial nerve was saved anatomically in 15 , or 65 per cent. of the cases. In all these cases except one, the nerve was so much traumatized during the operation that the homolateral side of the face was paralysed immediately following operation. In some of these cases a partial reaction of degeneration was observed some weeks after operation, and in the majority the reaction of degeneration was complete. In either case regeneration of the nerve took place within some months or a year (Fig. 1), though occasionally facial function failed to return.
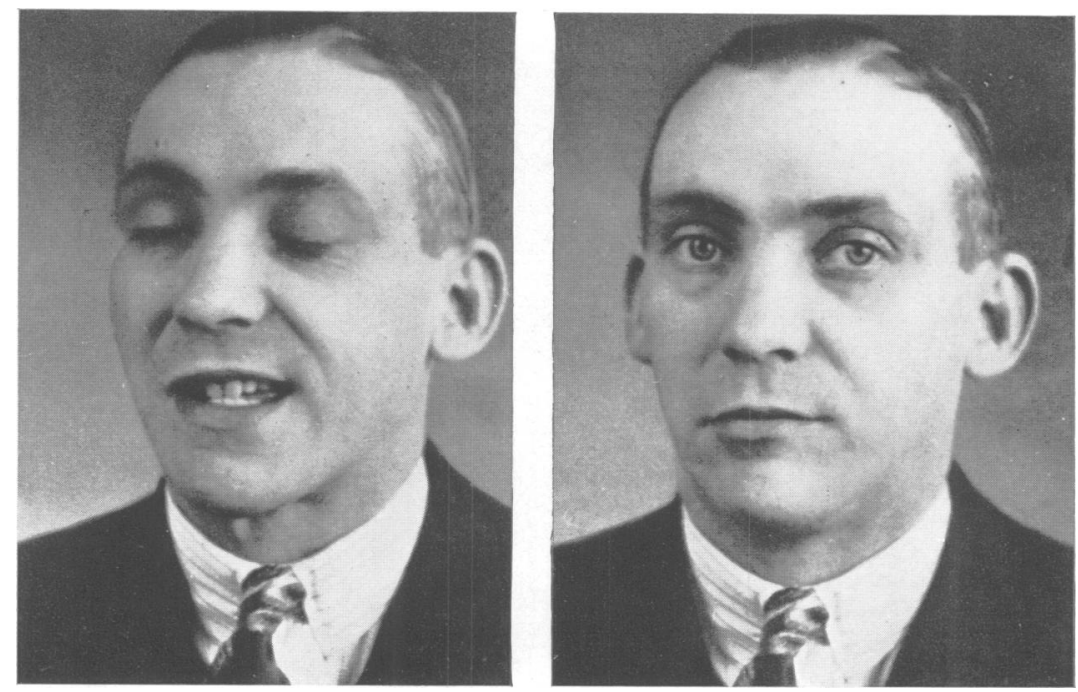

Fig. 1.-Case 7, 1937. Right sided acoustic tumour completely removed 1st January, 1937. Pictures taken May 1939. 
I have no doubt that these results can be improved upon and that the facial nerve can be saved in most cases where a complete removal is technically possible. The most important requisite in this respect is, as every neurosurgeon knows, that the "capsule" of the tumour should have a certain toughness.

My conclusions with regard to the policy to be pursued in acoustic tumours can be formulated in the following way. In cystic tumours nothing need be done except the removal of tags of tumour tissue from the cyst wall and cauterizing the latter with some fixative. In all other cases the complete removal of the tumour should be done if possible. However, if, after the lower pole has been mobilized it appears probable that the tumour, for technical or other reasons, cannot be completely removed or if the conservation of the facial nerve is of special urgency, care should be taken that the facial nerve is not injured during the remaining procedure, which terminates as a subtotal removal. In these cases a tiny bridge of tumour tissue is left covering the facial nerve and the side of the pons in the region of the emergence of the VIIIth and VIIth nerves, while the rest of the tumour is removed. For technical and other details I must refer to Dr. Nielsen's paper.

\section{Summary}

The mortality in radical operations in 75 cases of acoustic tumour, which is 18.7 per cent. in the whole series, has been brought down from 26.3 per cent. in the years 1931-33 to $11 \cdot 1$ per cent. in the years 1927-1939. During the last 2 years the facial nerve has been saved in 65 per cent. of the cases where the tumour was completely removed.

\section{REFERENCES}

List, C. F. (1932). Arch. klin. Chir., 171, 282.

Olivecrona, H. (1934). Ibid. ; 180, 445. 